EASTERN REVIEW 2015, T. 4

\title{
Wywiad z Michaiłem S. Gorbaczowem
}

\section{Gtasnost’ i pieriestrojka są nadal żywe i nie można ich zatrzymać}

Ludmiła J. Iljiczowa: Szanowny Michaile Siergiejewiczu! Grono rosyjskich uczonych przyjęło zaproszenie prof. Alicji Stępień-Kuczyńskiej do wzięcia udziału w październiku 2015 r. w konferencji Europejskie procesy modernizacyjne. Szanse $i$ wyzwania, której organizatorem jest Międzynarodowe Centrum Badań Wschodnioeuropejskich Uniwersytetu Łódzkiego. Organizatorzy konferencji wyodrębnili jako oddzielny blok tematyczny kwestię Pieriestrojka - krach czy zmiana? (poświęcony 30-leciu pieriestrojki).

Michaił S. Gorbaczow: Miło mi to słyszeć. Na wiele kwestii, które zamierzamy omówić, już udzielałem odpowiedzi w wywiadach dla czasopism, m.in. „Der Spiegel”, kanałów telewizyjnych, jak „Russia Today” czy „Rossija-1” itd.

Ludmiła J. Iljiczowa: Michaile Sergiejewiczu! Jest Pan liderem, który w roku 1985 został sekretarzem generalnym KPZR, był Pan przyjęty przez społeczeństwo jako przywódca całkowicie nowej formacji. Po krótkich rządach Andropowa i Czernienki to Pan przywrócił społeczeństwu poczucie dlugotrwałej stabilności. Zjednał Pan sobie ludzi swoją młodością, wystąpieniami bez kartek, wyjściami do ludzi i programem reform, których hasła - pieriestrojka [przebudowa - przyp. tłum.], uskorienije [przyspieszenie - przyp. tłum.], głasnost' [jawność - przyp. tłum.]" - na wiele lat stały się symbolami odnowienia kraju. Czym jest dla Pana pieriestrojka?

Michaił S. Gorbaczow: Miałem swoją wizję istoty kryzysu systemu radzieckiego, którego przyczyna polegała nie na wadach socjalizmu, a na wykorzystaniu w niewystarczającym stopniu jego możliwości. To właśnie spowodowało wytyczenie celów kursu reformatorskiego:

- pieriestrojka, tzn. wprowadzenie zmian strukturalnych i organizacyjnych;

- głasnost', tzn. uwypuklenie wszystkich wad, które zakłócały tempo rozwoju socjalistycznego;

- uskorienije, tzn. wyprowadzenie gospodarki radzieckiej na poziom światowy dzięki:

- bazowaniu na aktywnej twórczości mas,

- zwrotowi w stronę nauki, 
- priorytetowi sfery socjalnej,

- pozbyciu się skaz na socjalistycznym morale.

Ludmila J. Iljiczowa: Jak by Pan ocenił dzisiejsze procesy demokratyczne w Rosji?

Michail S. Gorbaczow: Głasnost' nie umarła, podobnie jak demokracja. W Rosji wyrosło nowe pokolenie, przy czym w całkowicie innych warunkach - znacznie większej wolności niż w Związku Radzieckim.

Istnieje przekonanie, że szybki rozpad ZSRR jest jedną z najbardziej istotnych przyczyn obecnego konfliktu na Ukrainie. Jednakże wówczas przeciwnicy pieriestrojki w otwartej walce politycznej ponieśli klęskę i postawili na eskalację, organizując pucz. Dążyli oni do przejęcia władzy i przy tym zniszczyli Związek Radziecki. Na dodatek jeszcze osłabili oni reformatorów. Borys Jelcyn, który objął władzę po mnie, „przepisał” krajowi terapię szokową, z powodu której Rosja cierpi do tej pory. Ja miałem program reform. Chociaż Związek Radziecki posiadał w swojej nazwie słowo „związek”, to nie był on prawdziwym związkiem. Republiki miały ograniczoną swobodę i uprawnienia. Dlatego też była przygotowana zreformowana umowa związkowa, której podpisanie było zaplanowane na 20 sierpnia 1991 r. Jednakże nomenklatura bała się nowych czasów i zniszczyła ZSRR.

Wzajemne oskarżenia o konflikt ukraiński nie pomogą rozwiązać tego szczególnie niebezpiecznego kryzysu. Zdecydowanie jednak chcę coś powiedzieć: w listopadzie 1990 r. w Paryżu na Konferencji Bezpieczeństwa i Współpracy w Europie mówiono o nowym i pokojowym porządku świata. W pierwszej kolejności za nim opowiadał się George Bush-senior. Jednak zamiast tego w Ameryce rozprzestrzeniła się niebezpieczna „mentalność zwycięzcy”. Za każdym razem, gdy przyjeżdżam do Stanów Zjednoczonych, to krytykuję to stanowisko. Wtedy wspominam Johna Kennedy'ego, który występował przeciwko demonizacji ludzi radzieckich i mówił, że prawdziwy pokój nie może być pokojem, który Ameryka będzie narzucała wszystkim pozostałym krajom: albo pokój będzie ogólny, albo pokoju nie będzie wcale. A czy Ameryka mogłaby zrealizować te wielkie zmiany bez Moskwy, bez nas? Nie! Wtedy zademonstrowaliśmy, co można osiągnąć wspólnie: zażegnaliśmy konflikty regionalne, doprowadziliśmy do zjednoczenia Niemiec, wyprowadzenia wojsk radzieckich z Europy Wschodniej i do rozbrojenia jądrowego. Ale później Ameryka niestety rozpoczęła budowanie imperium światowego - megaimperium.

Gdy rozpadł się ZSRR, nasi przeciwnicy płakali krokodylimi łzami, lecz pod stołem zacierali ręce z zadowolenia. Amerykanie zaczęli otaczać Rosję wszelkimi niby to obronnymi pierścieniami. NATO zaczęło się rozszerzać na wschód. Potem NATO bez akceptacji ze strony Rady Bezpieczeństwa ONZ wmieszało się w wojnę domową w Jugosławii. To był precedens. Wszystko to spowodowało reakcję zwrotną w Rosji. Ktokolwiek by nie zasiadał wtedy na Kremlu, nie mógłby zignorować tych wydarzeń. 
Jeśli brać pod uwagę dzisiejsze czasy, gdy Władimir Putin przyszedł na Kreml, to mu się trafiła ciężka spuścizna. Dookoła panował chaos. Gospodarka była w ruinie, całe regiony chciały się oddzielić od kraju. Rosji groził rozpad. W. Putin zatrzymał ten proces. To zawsze będzie uważane za jego wielką zasługę. Nawet gdyby więcej już niczego nie osiągnął, to o tym sukcesie nikt by nie zapomniał.

Ludmila J. Iljiczowa: Czy wierzy Pan, że Władimir Putin może zmienić kurs w obliczu dramatycznego kryzysu gospodarczego?

Michaił S. Gorbaczow: Właściwie to on nie ma się czego bać, bo nadal jest bardzo popularny. Jeśli W. Putin ma przeświadczenie, że inaczej już nie może, to wtedy będzie działał we właściwy sposób. Dzisiaj Rosja potrzebuje nowej pieriestrojki „od góry”, bo przeszła zaledwie pół drogi do demokracji, a drugą połowę dopiero jeszcze trzeba będzie przejść. Niestety, Kreml na razie stawia na linię konserwatywną.

Ludmila J. Iljiczowa: Dlaczego Pan uważa sankcje za błąd?

Michail S. Gorbaczow: One szkodzą gospodarkom obu krajów. Błędem było również wyłączenie Rosji z G8. To przypomina krwawą zemstę i wiedzie donikąd. Sankcje nie są odpowiednim instrumentem, gdy chcemy utrzymać dobre stosunki.

Nie wolno dopuścić do tego, by dobre stosunki stały się przeszłością. Po upadku Muru Berlińskiego w stosunkach między Niemcami a Rosją nastąpił ogromny postęp. Zbudowaliśmy wyjątkowe, bardzo dobre relacje. Nie wolno ich w żadnym wypadku niszczyć. Obecnie Zachód przeszkadza Rosji brać udział w rozwiązywaniu problemów globalnych: walce z terroryzmem i „państwem islamskim" oraz ochronie środowiska. Ale co w tym dobrego? My znów powinniśmy osiągnąć ocieplenie w naszych stosunkach - pilnie potrzebujemy nowej odwilży! My, Rosjanie, w tym celu zrobimy wszystko. Sądzę, że Rosja będzie prowadzić swoją politykę w tym kierunku. Jednak w Niemczech zdaje się, że są siły rywalizujące ze sobą o to, kto przejawi w stosunku do Rosji więcej okrucieństwa.

Ludmiła J. Iljiczowa: Jakie jest według Pana wyjście z tego kryzysu?

Michaił S. Gorbaczow: Trzeba niezwłocznie ogłosić rozejm. Następnie należy rozpocząć międzynarodową akcję w sprawie odbudowy zniszczonych regionów. W razie konieczności należy znów zaprosić Otto von Bismarcka, który kiedyś powiedział, że Niemcy nigdy nie powinny prowadzić wojny przeciw Rosji. Niemcy już próbowały w czasie II wojny światowej rozszerzyć swoją strefę wpływów na wschód. Jakiej jeszcze lekcji potrzebują? W moim kraju nikt nie zapomniał ani straszliwych zniszczeń, ani tego, jak żony czekały na powrót swoich mężów z frontu, a ci niestety nie powrócili. Dobrze, że nasze narody później się pogodziły. 
Proszę sobie przypomnieć przemówienie W. Putina na Konferencji Bezpieczeństwa w Monachium w 2007 r. On już wtedy ściśle określił, w którym miejscu dla Rosji przebiega „czerwona linia” i dał do zrozumienia, że nie zgadza się na przybliżenie NATO do jej granic. Tak więc, dlaczego nasi partnerzy są teraz zdziwieni? Mam takie wrażenie, że naród niemiecki zrozumiał Putina lepiej niż niemieckie elity.

$* * *$

Michaił Siergiejewicz jest ciągle oddany pracy i w swoich najbliższych planach ma zamiar nadal uczestniczyć w dyskusji o przyszłości Rosji, pokoju na całym świecie, ochronie środowiska, pisać książki, występować z wykładami, brać udział w konferencjach, udzielać wywiadów.

Głasnost'i pieriestrojka są nadal żywe i nie można ich zatrzymać.

Ludmiła J. Iljiczowa

Profesor Rosyjskiej Akademii Gospodarki Narodowej i Administracji Publicznej przy Prezydencie FR Wywiad przeprowadzony w sierpniu $2015 \mathrm{r}$. 
EASTERN REVIEW 2015, T. 4

\section{Интервью с Михаилом С. Горбачевым}

\section{Гласность и перестройка по-прежнему живы, и их невозможно остановить}

Людмила Е. Ильичева: Уважаемый Михаил Сергеевич! Мы российские ученые, приняли приглашение профессора Алиции Стемпень-Кучиньской (Польша) принять участие в декабре 2015 года в международной конференции Европейские модернизационные процессы. Вызовы и шансы, организуемой Международным центром исследований Восточной Европы Лодзинского университета. Организаторы конференции выделили в отдельный тематический блок тему Перестройка - крах или перемены? (посвященный 30-летию перестройки).

Михаил С. Горбачев: Отрадно слышать. На многие вопросы, которые мы собрались обсудить, я уже давал ответ в интервью журналам „Der Spiegel. Германия”, телевизионному каналу „Russia Today”, телевизионному каналу „Россия-1” и т.д.

Людмила Е. Ильичева: Михаил Сергеевич! Вы лидер, ставший в 1985 г. генеральным секретарём КПСС, были встречены обществом как лидер совершенно новой формации. После коротких правлений Андропова и Черненко Вы вернули обществу ощущение долгосрочной стабильности.

Людей подкупала Ваша молодость, выступления без бумажек, выходы в народ и программа реформ, лозунги которой - перестройка, ускорение, гласность - на несколько лет превратились в символы обновления страны. Что для Вас перестройка?

Михаил С. Горбачев: Я имел свое видение природы кризиса советской системы: причина которого лежала не в недостатках социализма, а в недостаточном использовании его возможностей. Это и предопределило цели реформаторского курса:

- перестройка, т.е. внесение структурных и организационных изменений;

- гласность, т.е. выявление всех недостатков, препятствовавших ускорению социалистического развития; 
- ускорение, т.е. вывод советской экономики на мировой уровень за счёт:

- опоры на живое творчество масс;

- поворота к науке;

- приоритета социальной сферы;

- избавления от искажений социалистической морали.

Людмила Е. Ильичева: Как бы Вы оценили демократические процессы в России сегодня?

Михаил С. Горбачев: Гласность не умерла, как и демократия. В России выросло новое поколение людей, причем в совершенно иных условиях - в условиях гораздо большей свободы, чем в Советском Союзе.

Бытует мнение, что стремительный распад СССР является одной из глубинных причин нынешнего конфликта на Украине. Однако, в тот период в открытой политической борьбе противники перестройки потерпели поражение и сделали ставку на эскалацию, организовав путч. Они стремились к власти, но разрушили при этом Советский Союз. А еще они ослабили реформаторов. Борис Ельцин, пришедший к власти после меня, „прописал” стране шоковую терапию, от которой Россия страдает до сих пор. У меня была программа реформ. Хотя Советский Союз имел в своем названии слово „союз”, он не был настоящим союзом. У республик были лишь ограниченные свобода и полномочия. Поэтому был подготовлен реформированный союзный договор, подписание которого было запланировано на 20 августа 1991 года. Но номенклатура боялась новых времен и разрушила Союз.

Взаимные обвинения в украинском конфликте не помогут урегулировать этот чрезвычайно опасный кризис. Однако кое-что хочу сказать определенно: в ноябре 1990 года, на Конференции по безопасности и сотрудничеству в Европе в Париже, речь шла о новом и мирном миропорядке. В первую очередь, за него выступал Джордж Буш-старший. Однако вместо этого в Америке получил распространение опасный „менталитет победителя”. Я критикую эту позицию каждый раз, когда приезжаю в Соединенные Штаты. Тогда я вспоминаю Джона Кеннеди, который выступал против демонизации советских людей и говорил, что настоящий мир не может быть миром, который Америка будет навязывать всем остальным странам: либо мир будет общим, либо мира не будет вовсе. - А разве Америка смогла бы достичь этих грандиозных изменений без Москвы, без нас? Нет! Мы тогда продемонстрировали, чего можно добиться сообща: мы урегулировали региональные конфликты, добились воссоединения Германии, вывода советских войск из Восточной Европы и ядерного разоружения. Но потом Америка, к сожалению, начала строить мировую империю - мега империю.

Когда распался СССР, наши противники лили крокодиловы слезы, но под столом довольно потирали руки. Американцы начали окружать Россию всевозможными, якобы оборонительными кольцами. НАТО стал расширять- 
ся на восток. Потом НАТО без одобрения со стороны Совета Безопасности ООН вмешался в гражданскую войну в Югославии. Это стало прецедентом. Все это вызывало ответную реакцию в России. Кто бы ни находился в это время в Кремле - он не мог игнорировать эти события.

Если говорить о сегодняшнем времени, то, когда Владимир Путин пришел в Кремль, ему досталось тяжелое наследие. Повсюду царил хаос. Экономика лежала в руинах, целые регионы хотели отделиться от страны. России угрожал распад. Путин остановил этот процесс. Это навсегда останется его большой заслугой. Даже если бы В. Путин не добился больше ничего, этого его достижения никто не забыл бы.

Людмила Е. Ильичева: Вы верите в то, что Владимир Путин может изменить курс ввиду драматического экономического кризиса?

Михаил С. Горбачев: Вообще-то, ему нечего бояться, потому что он по-прежнему очень популярен. Если у В. Путина возникнет ощущение, что он иначе уже не может, то он и будет действовать соответствующим образом. Сегодня России нужна новая перестройка „сверху”, Россия преодолела лишь половину пути к демократии, а вторую половину еще только предстоит преодолеть. К сожалению, Кремль делает ставку пока на консервативную линию.

Людмила Е. Ильичева: Почему вы считаете санкции ошибкой?

Михаил С. Горбачев: Они вредят экономике обеих сторон. Ошибкой было также исключать Россию из „Большой восьмерки”. Это чем-то похоже на кровную месть и ведет в никуда. Санкции не являются подходящим инструментом, если мы хотим сохранить добрые отношения.

Нельзя допустить, чтобы добрые отношения остались в прошлом - после падения Берлинской стены в отношениях между Германией и Россией был достигнут огромный прогресс. Мы построили уникальные, очень хорошие отношения. Их ни в коем случае нельзя разрушать. Сейчас Запад мешает России участвовать в решении глобальных проблем: в борьбе с терроризмом и „Исламским государством”, в защите окружающей среды. Но что в этом хорошего? Мы должны вновь добиться потепления в наших отношениях - нам срочно нужна новая оттепель! Мы, россияне, все сделаем для этого. Я думаю, что Россия будет вести свою политику в этом направлении. Однако в Германии, похоже, есть силы, соревнующиеся друг с другом в том, кто проявит по отношению к России больше жесткости.

Людмила Е. Ильичева: Каков выход из этого кризиса, на Ваш взгляд?

Михаил С. Горбачев: Нужно немедленно объявить перемирие. Затем должна начаться международная акция по восстановлению разрушенных регионов. В случае необходимости, нужно вновь пригласить Отто фон Бисмарка, который когда-то сказал, что Германии никогда не следовало бы 
вести войну против России. Германия уже попыталась - во время Второй мировой войны - расширить свою сферу влияния на восток. Какой еще урок нужен ей? В моей стране никто не забыл ни ужасных разрушений, ни того, как жены ждали своих мужей с фронта, а те так и не вернулись. Хорошо, что наши народы потом помирились.

Вспомните, пожалуйста, речь В. Путина на Мюнхенской конференции по безопасности 2007 года. Он уже тогда четко обозначил, где для России пролегает „красная линия”, и дал понять, что она не согласна с приближением НАТО к ее границам. Так что, чему наши партнеры теперь удивляются? У меня такое впечатление, что немецкий народ понял Путина лучше, чем немецкие элиты.

***

Михаил Сергеевич по-прежнему привержен работе и в его ближайших планах: так же как и раньше участвовать в дискуссии о будущем России, о мире во всем мире, о защите окружающей среды, писать книги, читать лекции, участвовать в конференциях, давать интервью.

Гласность и перестройка по-прежнему живы, и их невозможно остановить.

Людмила Е. Ильичева

Доктор политических наук, профессор РАНХиГС при Президенте РФ Интервью взято в августе 2015 г. 
EASTERN REVIEW 2015, T. 4

\section{An interview with Mikhail S. Gorbachev}

\section{Glasnost and perestroika are still alive and cannot be stopped}

Ludmila J. Ilichova: Dear Mikhail Sergeevich! A group of Russian scholars have accepted an invitation from prof. Alicja Stępień-Kuczyńska to participate in an international conference organized by the International Centre for East European Research on European modernization processes. Opportunities and challenges, to be held in October 2015. The organizers have highlighted the $30^{\text {th }}$ anniversary of perestroika, making it a separate thematic bloc entitled Perestroika - a failure or a transformation?

Mikhail S. Gorbachev: I am glad to hear it. I have already touched on many questions we are going to discuss today in interviews for journals, e.g. „Der Spiegel”, or TV channels, such as „Russia Today” or „Rossija-1”.

Ludmila J. Ilichova: Mikhail Sergeevich! When you became the First Secretary of the Communist Party of the USSR, you were perceived by the society as a leader of an entirely new political formation. After the short rules of Andropov and Chernienko, you were the one who gave the people the renewed feeling of long-term stability. You owed your popularity to your young age, spontaneous speeches, face-to-face contact with the people, and, ultimately, your reform platform, with the slogans of perestroika (reconstruction), uskorienie (acceleration) and glasnost (openness) - which were to become the symbols of the country's revival for years to come. What does perestroika mean to you?

Mikhail S. Gorbachev: I started with the diagnosis of the crisis of the Soviet system: it was caused by insufficiently exploiting the potential of socialism, not by its intrinsic deficiencies. Therefore, the goals of the reform were:

- perestroika, i.e. structural and organizational changes;

- glasnost, i.e. openly admitting to all obstacles that obstructed the socialist development;

- uskorienie, i.e. improving the Soviet economy to the world level through:

- using creative activity of the masses,

- turning to science,

- attaching priority to the social sphere,

- improving on the socialist morality. 
Ludmila J. Ilichova: What is your assessment of contemporary democratization processes in Russia?

Mikhail S. Gorbachev: Głasnost is alive, as is democracy. A new generation grew in Russia in the environment of much more freedom than in the USSR.

There is a conviction that the rapid dissolution of the USSR is one of the main reasons of the recent conflict in Ukraine. However, the opponents of the perestroika lost in the open political struggle and they chose to escalate the conflict by organizing a putsch. Vying for power, they destroyed the USSR, and they weakened the position of the reformers, to boot. Boris Yeltsin, my successor, prescribed Russia a shock therapy from which the country has never really recovered. I did have the reform program. Soviet Union, despite its name, was not a real union: the freedom and rights of the republics were limited. In view of that, a new federal agreement was prepared to be signed on the $20^{\text {th }}$ of August 1991. Unfortunately, the nomenclature feared the new future and destroyed the Union.

Mutual accusations will not contribute to solving the Ukrainian conflict - a particularly dangerous crisis. But let me emphasise something. When in 1990 in Paris, during the Conference of Security and Co-operation in Europe, the new peaceful world order was discussed, George Bush Sr. was among its foremost supporters. Instead, a "winner's mentality" triumphed in America. I criticize this posture whenever I come to the USA. I then recall John F. Kennedy who protested against demonizing the Soviet people. He said that the true peace cannot be imposed by America on other nations: peace must be universal, or it cannot exist at all. And would America be able to bring on these grand changes without Moscow, without us? No! We have shown what can be achieved by acting in concert: we extinguished regional conflicts, withdrew Russian troops from Eastern Europe, started nuclear disarmament and made the unification of Germany possible. Unfortunately, America proceeded to build the world empire - a megaempire.

When the USSR collapsed, our opponents shed crocodile tears, but in fact were only too glad. Americans began to surround Russia with all kinds of allegedly defensive rings. NATO started its eastward expansion. Then, without the authorization of the UN Security Council, it intervened into a civil war in Yugoslavia. It set a precedence. All of these triggered a reaction in Russia. Whoever was in charge at Kremlin at this time could not have afforded to ignore these developments.

When Vladimir Putin took over, he inherited a troubled situation. Chaos was all around. The economy was in ruin, whole regions wished to separate from Russia. The country was threatened with dissolution. Putin managed to stop this process. This will always count as his great accomplishment, even if he never achieves anything else. 
Ludmila J. Ilichova: Can Vladimir Putin, in your opinion, change his course in the face of the dramatic economic crisis?

Mikhail S. Gorbachev: As a matter of fact, he has nothing to be afraid of - he remains very popular. When Putin feels there is no alternative, he does the right things. Today Russia needs a new perestroika "from above", because it made it only half way towards democracy, with the other half still ahead. Unfortunately, Kremlin has been quite conservative so far.

Ludmila J. Ilichova: Why do you regard sanctions a mistake?

Mikhail S. Gorbachev: They are detrimental to the economies of both countries. Excluding Russia from G8 was also a mistake. It smacks of a bloody revenge and leads nowhere. The sanctions are not a proper instruments for those who want to retain good relations.

Let's not destroy what has been achieved. After the fall of the Berlin Wall, there has been an enormous progress in German-Russian relations. They have been exceptionally good. We cannot afford to destroy them. Nowadays the West obstructs Russia's attempt to contribute to solving global problems: the war on terrorism and the "Islamic state", environmental protection. Is it any good? Our relations should warm up again - we need a new rapprochement now! We, Russians, are very determined to achieve it. This, I think, will be the direction of the Russian policy. But in Germany there seems to be a challenge among political forces of who will take a more severe stand towards Russia.

Ludmila J. Ilichova: What is the way out of the crisis?

Mikhail S. Gorbachev: A truce has to be announced as soon as possible. Then, an international action to rebuild the destroyed regions should follow. If necessary, let us invite Otto von Bismarck again, who once said that Germany should never wage war against Russia. There was a time, during WWII, when Germany tried to expand their sphere of influence eastwards. Do they need another lesson? In my country, the memory of the terrible destruction and of wives awaiting in vain the return of their husbands is still vivid. Fortunately, our two nations have since reached a reconciliation.

Recall W. Putin's speech during the security conference in Munich in 2007. He stated clearly where the "red line" for Russia is, and hinted that he would not accept NATO's approach to its borders. Why, then, are our partners now surprised? I have an impression that the German nation understands Putin better than do the German elites.

Mikhail Sergeevich is still devoted to his work. His plans for the nearest future include taking part in debates about the future of Russia, peace in the world, 
and protection of environment, as well as writing books, lecturing, participating in conferences, giving interviews.

Glasnost and perestroika are still alive and cannot be stopped.

Ludmila J. Ilichova

Professor of the Russian Academy of National Economy and Public Administration, affiliated with the President of Russian Federation Interview conducted in August 2015 